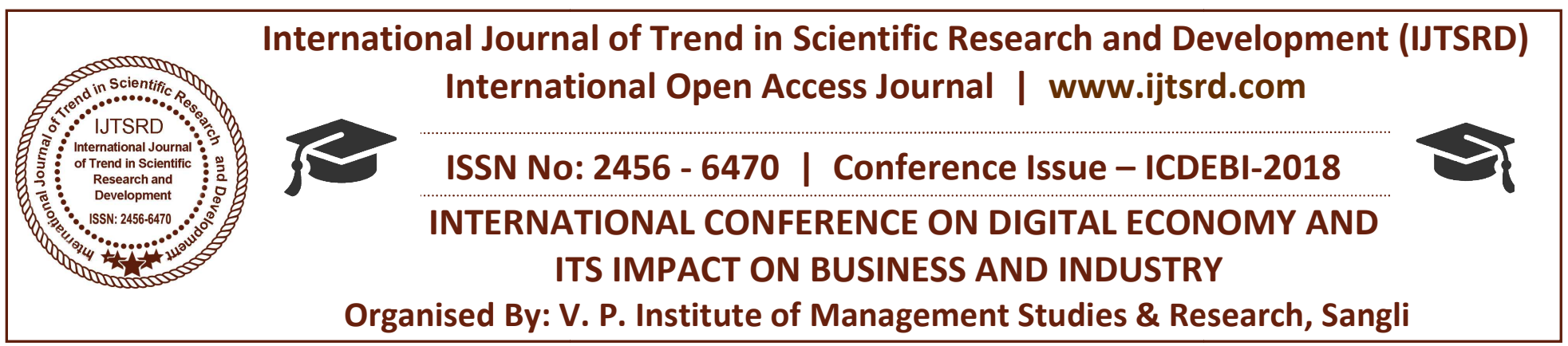

\title{
Financial Performance of Digital Banking Sector in India
}

\author{
M. Siddarth \\ Department of Commerce, GUK
}

\begin{abstract}
The banking sector is the one of important in financing general thinking which builds much of the financial performance in the modern digital world, growing financial performance lead to improving better functions of an organization. The main objective of this article is to know about the financial performance of Indian public sector banks in the random banks have been selected for the study. Financially stabilized manner some of the variables selected for the study to interpret financial performances like loans and advances, assets, equity shareholder capital, deposits, and net profit margin.
\end{abstract}

\section{INTRODUCTION}

Banking sector plays a vital role in the economic development of a nation; the Banking system of India has a wide network of branches serving a number of services to the people. Efficient Banking system shows the development of nation economically and it proved many times, for example, the subprime crisis period, while every country has gone bankrupt even though the Indian banking sector faced many difficulties but due to efficient financial strength it makes the financial system to maintain the good financial condition. Indian Banking sector have public sector-private sector and foreign sector working in India with their respective competition to other, these banks differ significantly from each other in terms of financial performance.

The economic environment changing all around the world after the global financial crisis, the financial structure in globally has been also change due to slow down. Banking sector is also affected by the crisis. Banking sector is the main component of financial activities therefore measuring the strength and financial soundness of banking institution has become a major task. The functioning of banking sector has change upside down in India also. To check the efficiency of banking system in India, their financial performance is determination. So it is important to evaluate as to the performance of banks has improved after crisis. Such information can provide use full for further route map, to policy maker about understanding the efficiency of banking sector in India.

Today Indian banking Sector is a flourishing Industry; it's mainly focused on new Banking technological innovations. Banks innovated to use digital tool to provide effective quality and services to the customer and get high speed in less time with wide area coverage of customers. In the recent scenario it has been changed, there are around 340 banks are working in India, in which are public and private banks. Today all the banks started with the different channels, like, Credit Cards, Debit Cards, Mobile Banking, Internet Banking, E-pay etc. In 2020 Indian banking sector will be fifth largest banking sector and in 2025 third largest banking sector in the world.

The main object of the study is to compare the Financial Performance of the Indian Public Banking Sector. For the analysis secondary data has been chosen to know the financial performance of banks. The financially stabilized manner some of the variables have been selected for the study to analyze the financial performance like loans and advances, assets, equity shareholder capital, deposits, and net profit margin. 
ANALYSIS AND INTERPRETATION

ASSETS

\begin{tabular}{|c|c|c|c|c|c|}
\hline & 2017 & 2016 & 2015 & 2014 & 2013 \\
\hline Canara & 3885 & 3365 & 5480 & 4919 & 4123 \\
bank & 18 & 45 & 0.56 & 21.85 & 42.61 \\
\hline Union bank & 3193 & 3163 & 3816 & 5357 & 3118 \\
of India & 83 & 93 & 15.93 & 80.90 & 60.81 \\
\hline
\end{tabular}

The above table refers to the Total Assets rate of the selected banks for a time period. Here also the Canara bank was in first so it represents the good opinion among the other selected banks. Assets represent the total reserves of the banks. So here the reserves mean that all banks have improved in reserves too.

ADVANCES

\begin{tabular}{|c|c|c|c|c|c|}
\hline & $\mathbf{2 0 1 7}$ & $\mathbf{2 0 1 6}$ & $\mathbf{2 0 1 5}$ & $\mathbf{2 0 1 4}$ & $\mathbf{2 0 1 3}$ \\
\hline Canara & 3102 & 2680 & 3300 & 3010 & 2421 \\
bank & 1 & 1 & 35.51 & 67.48 & 76.62 \\
\hline Union bank & 3193 & 2777 & 2556 & 2291 & 2081 \\
of India & 83 & 25 & 54.57 & 04.43 & 02.19 \\
\hline
\end{tabular}

The above table refers to the Advances rate of the selected banks for the time period./In Bank, the Advances represent the assets to the bank because the customers used to pay interest to the bank so it represents the income to banks. All the selected banks are improved all the selected year. Comparing with the banks Union bank performed better to compare with other banks.

\section{DEPOSIT}

\begin{tabular}{|l|l|l|l|l|l|}
\hline & 2017 & 2016 & 2015 & 2014 & 2013 \\
\hline Canara bank & 5038 & 5103 & 4738 & 4207 & 3558 \\
& 88 & 27 & 40 & 22 & 55 \\
\hline $\begin{array}{l}\text { Union bank } \\
\text { of India }\end{array}$ & 3783 & 3427 & 3168 & 2976 & 2637 \\
& 92 & 20 & 69 & 75 & 61 \\
\hline
\end{tabular}

The above table refers to the Deposits rate of the selected banks for the time period. In Bank, the deposits represent the liabilities to the bank. All the selected banks are improved all the selected year. Comparing with the banks Canara banks performed better to compare with other banks.

\section{EQUITY SHAREHOLDERS CAPITAL:}

Equity share capital represents issuing the shares to the public or third person to improve the cash for the company or banks for that bank will pay the dividend to the share holders. The amount of share capital changes time to time to improvise the share capital.

\section{RETURN ON EQUITY:}

$\mathrm{ROE}$ is the amount of net income returned as a percentage of shareholders' equity. Return on equity measures a corporation's profitability by revealing how much profit a company generates with the money shareholders have invested.

\section{RETURN ON ASSET:}

Return on assets indicates that the profitable factors of the banks which related to total assets. The higher return, more efficient management is in utilizing its asset base. And ratio is calculated by comparing net income to average total asset, and is expressed as a percentage.

\section{NET PROFIT MARGIN:}

It is the revenue left after all expenses deducted from sales, the measurement shows the amount of profit that a business can extract from its total sales. The net sales part of the equation is gross sales minus all sales deductions, such as sales allowances.

\section{CONCLUSION}

The selected variables provide different meaning like assets and liabilities of the banks. The results prove that in there of deposits, loans and assets the Canara bank performs well during the selected period of time. Both deposits and loans are in the better way compared to other banks. NPM has been reduced for all the banks. To conclude the study some factors in total they have a good volume of exposure but the ratios are coming down so the banks should concentrate on every possible move for better growth. In the perspective of this domestic and international development, the banking sector has to chart out a perfect path for the development in its own.

\section{REFERENCES}

1. Nathwani, Nirmal (2004) the Study of Financial Performance of Banking Sector of India. Ph.D. thesis, Saurashtra University.

2. Anurag. B. Singh; Ms. Priyanka Tandon (2012), A Study Of Financial Performance: A Comparative Analysis Of SBI And ICICI Bank, "International Journal of Marketing, Financial Services \& Management Research" Vol.1 Issue 11, November 2012, ISSN 22773622.

3. Premalata KCTBS, Comparison of Financial Performance in Banking Sector Evidence from Indian Public Sector Banks. IJRTD Volume 3. 
International Journal of Trend in Scientific Research and Development (IJTSRD) ISSN: 2456-6470 | IF: 4.101

4. Medhat (2006), Comparison of Financial Performance in the Banking Sector: Some Evidence from Omani Commercial Banks, "International Research Journal of Finance and Economics” ISSN 1450-2887 Issue 3 (2006).

5. M. Kavitha (2012), Financial Performance Of Selected Public Sector Banks In India, "International Journal of Multidisciplinary Research" Vol.2 Issue 1, January 2012, ISSN 22315780 .
6. Sanjeev Kumar Srivastav (2013), “A Financial Ratio Analysis Of Select Foreign And New Private Sector Banks Operating In India", "The International Journal Of Management" ISSN 2277-5846 Vol 2 Issue 4 (October 2013), pp 2834.

7. Siva Reddy Kalluru (2009), "Ownership Structure, Performance, and Risk in Indian Commercial Banks", "The IUP Journal of Applied Finance”, Vol. 15, No. 8, 2009 pp 31-45.

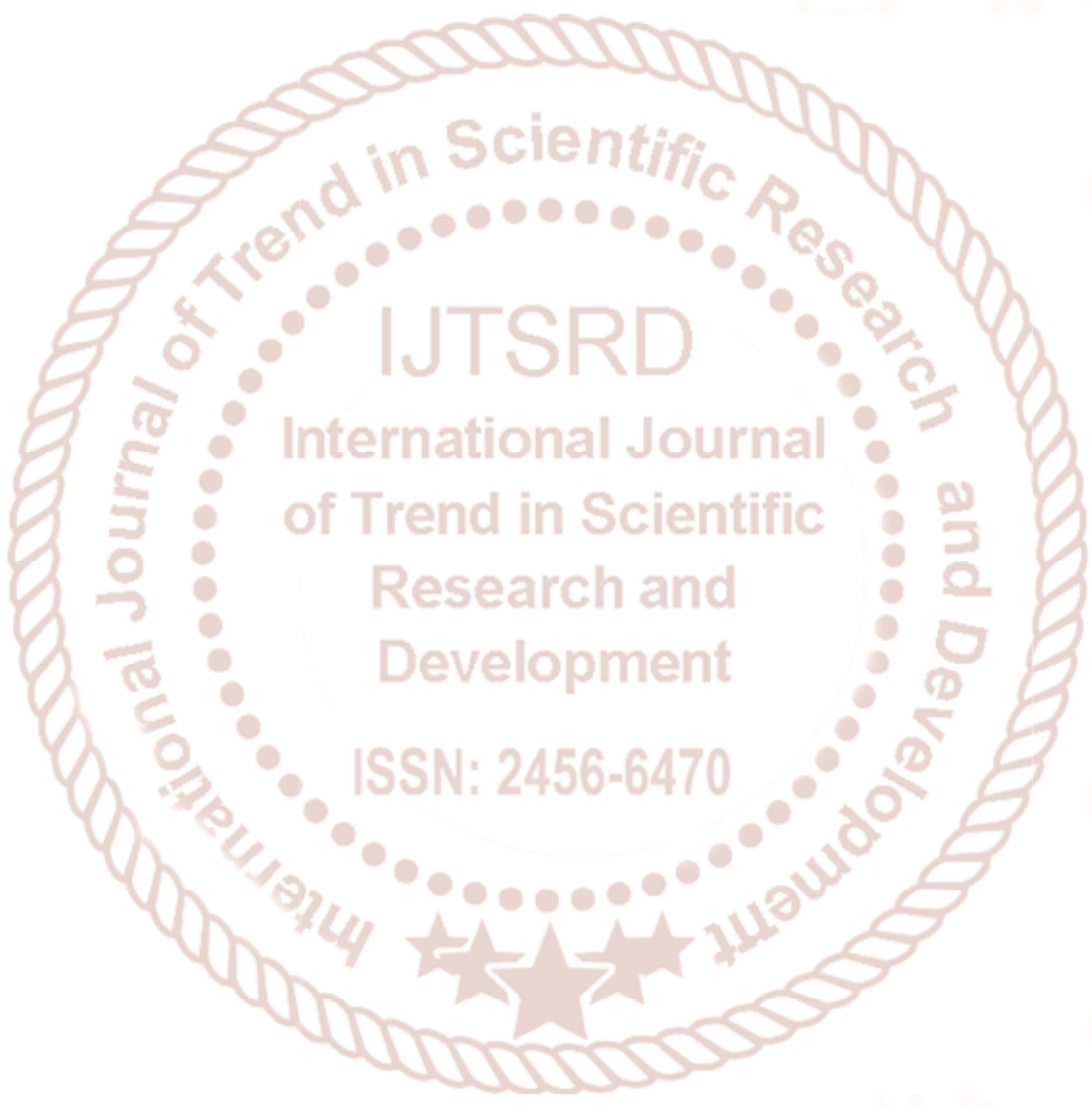

